\title{
Impact of Enterprise's Microblogging Marketing on Customer Purchasing Behavior Base on Improved TAM Model
}

\author{
An $\min ^{1 *}$ He Weijun ${ }^{2}$, Lyu Yiying ${ }^{2}$, Yuan Liang ${ }^{1}$ and Dagmawi Mulugeta Degefu ${ }^{3}$ \\ ${ }^{1}$ Business School of Hohai University, Nan Jing211100, China \\ ${ }^{2}$ College of Economics and Management, Three Gorges University, \\ Yichang443002, China \\ ${ }^{3}$ College of Hydraulic and Environmental Engineering, Three Gorges \\ University, Yichang443002, China \\ 1*616614429@qq.com, ${ }^{2}$ weijunhe@ctgu.edu.cn, ${ }^{2}$ lyy9421@qq.com, \\ ${ }^{1} 398827404 @ q q . c o m,{ }^{3}$ degefu@ctgu.edu.cn
}

\begin{abstract}
s
Micro-blog as one of the main network platform for real-time sharing in the Internet, its impact is increasing. Enterprises try their best to explore the microblogging marketing's great potential, which is of great significance for them increasing corporate profits and enhancing brand awareness. This paper firstly reviews the domestic and foreign marketing research for enterprise microblogging; secondly the article have an in-depth inquiry in AISAS model and characteristics of micro blogging marketing, use the optimized ATM model as the theoretical basis of the research; then the essay take the typical case of millet technology enterprise microblogging marketing as example and design questionnaires, collect data, use structural equation model fitting the data to judge and correction. It is concluded that the external variables have a significant impact on the users' perception; both the users' perception perceptual attitude toward participation attitude and participation attitude toward purchasing behavior have significant effects, while the psychological motivation has no significant impact on the users' perception. On this basis, we put forward that the micro-blog marketing should focus on promote the brand influence and value, analysis the target market and position precisely, encourage customers to share and shape the actual usefulness of products and so on.
\end{abstract}

Keywords: TAM model, structural equation analysis, enterprises, micro-blog marketing

\section{Introduction}

In the wheel of history, the technology continue to drive mankind creating the new world. The Internet, with the power of change everything, is setting off a profound impact on all levels of human change in the global scope. Microblogging as one kind of network media has the quality of fission, its propagation speed is much higher than any other kind of media products before; combine with its flexibility, refine, timeliness, share and many other features which make the micro-blog become the best node link with the Internet and the user; at the same time microblogging's effective and efficient information dissemination capabilities make the enterprises can be more flexible, effective and independent when publish enterprise marketing information to the customer. Therefore, many companies have seized the hot social media to carry out marketing microblogging craze, create a good brand image and deliver a positive message on the microblogging platform to promote the offline product promotion, improve visibility, train fan base, let the brand to reach a broader group of users so that achieve the optimal value, and

$1 *$ Corresponding author 
gradually open the wave of microblogging marketing.

From the day real-time sharing platform produce (foreign Twitter, domestic mainly sina weibo),domestic and foreign scholars are in-depth analysis microblogging's nature, effect and so on. There also have so many research on Enterprises' microblogging marketing. Concerned the abroad, Court(2009) [1], Park(2011) [2] use the method of instance and TAM model respectively and analysis the impact of enterprise microblogging marketing from a user point of view; Bernard Jansen (2009) [3], Ehrlich (2010) [4] use big data to study the impact of the positive evaluation and negative news on the enterprise micro-blog's marketing reputation; Avila (2011) [5] analysis and confirm that release labels in the micro-blog marketing is a method can help enterprises to accurately locate potential customers; Kim Annice E, Hopper Timothy(2015)[6]use the method of comparative analysis from cigarette of micro-blog's marketing data and get out the effectiveness of the microblog marketing. After the birth of sina weibo In august 2009 China, domestic scholars have gradually relatively independent research on enterprise microblog marketing, Wumin (2010) [7] combine with successful cases of domestic and foreign enterprise microblogging marketing and propose to establish and use media microblogging marketing; Wang Hailong (2011) [8], Lu Yan (2011) [9] analysis the enterprise micro-blog marketing examples and propose the program to enhance the enterprise micro-blog marketing effectiveness; Yao Qian and Bu Yanfang (2011) [10], Wang Rui (2012)[11] discuss enterprise microblogging influential factors by using qualitative and quantitative methods respectively, measure short-term effect, and put forward the microblogging marketing strategy; Dong Yu (2011) [12], Zhou Beijing and Hou Lun (2011) [13], Ning Jinpeng and Wang Xiaoyu (2011) [14] with the methods of questionnaire, TAM and IDT model, unify user data fusion model algorithm respectively to study consumers' acceptance and the extent of reaction for enterprise microblogging marketing from the consumer point, to enable enterprises more efficiently expand microblogging marketing activities; Fu Ying (2013) [15], Zhao Sanshan (2014) [16], Han Mei and He Yue (2015) [17] use different methods to identify enterprise microblogging marketing factor, establish evaluation indicators to quantify the enterprises' microblogging marketing effectiveness; Ge Jinping and Shao Liqing (2012) [18], Chen Hang (2014) [19], Jiangjia Yan (2015) [20] respectively from the movie, sports goods enterprises ,luxury car brand microblogging's personalized marketing study different industry enterprise microblogging marketing strategy.

From the point of domestic and foreign research, TAM model is widely used in the microblogging marketing study, but use TAM model for scientific selection factors are still exist certain defects, for further study it did not combined the TAM model with the nature of the network marketing (search - spread - sharing).This paper selected representative millet science and technology enterprises' microblogging, combine with optimized TAM model to analysis of the influence factors, use the DEA model to calculate the important degree of each influencing factor, at last in a certain extent give guidances to the enterprise microblogging run.

\section{Related Methods}

\subsection{TAM Model}

Davis, an American scholar, propose the technology acceptance model (Acceptance Model Technology, TAM) in his doctoral dissertation in 1986, which is used to predict the behavior subject to accept, use or reject information technology or information system [21].The specific model of TAM is just as shown in Figure 1: 


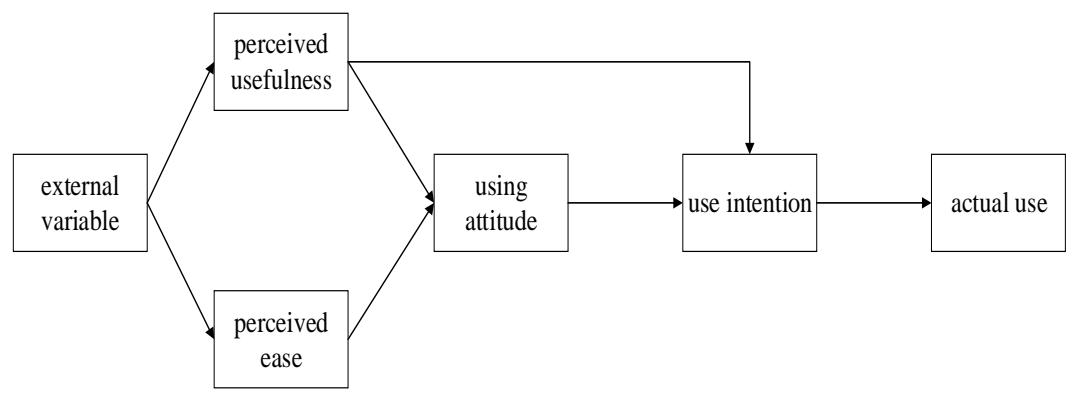

Figure 1. TAM Model Flow Chart

This model is widely used by scholars to predict and explain the behavior of users' when they use information system. It is believed that user intention actors determine the actual use, intention to use is determined by using attitude and perceiving usefulness; Perceived usefulness and perceived ease of use together have a positive affect to the use of attitude, behavior subject get more information about perceived information systems useful and easy to use, the more likely for them to form a positive attitude and willingness, thus more likely to actually use the information system; Perceived ease of use together with external variables impact perceived usefulness, perceived ease of use influenced by external variables.

\subsection{AISAS Model}

Based on the emergence of the network shopping patterns and their irreversible, Dentsu upgrade the traditional AIDMA model to the AISAS behavior model base on the characteristics of the network market. The specific process is shown in Figure 2:

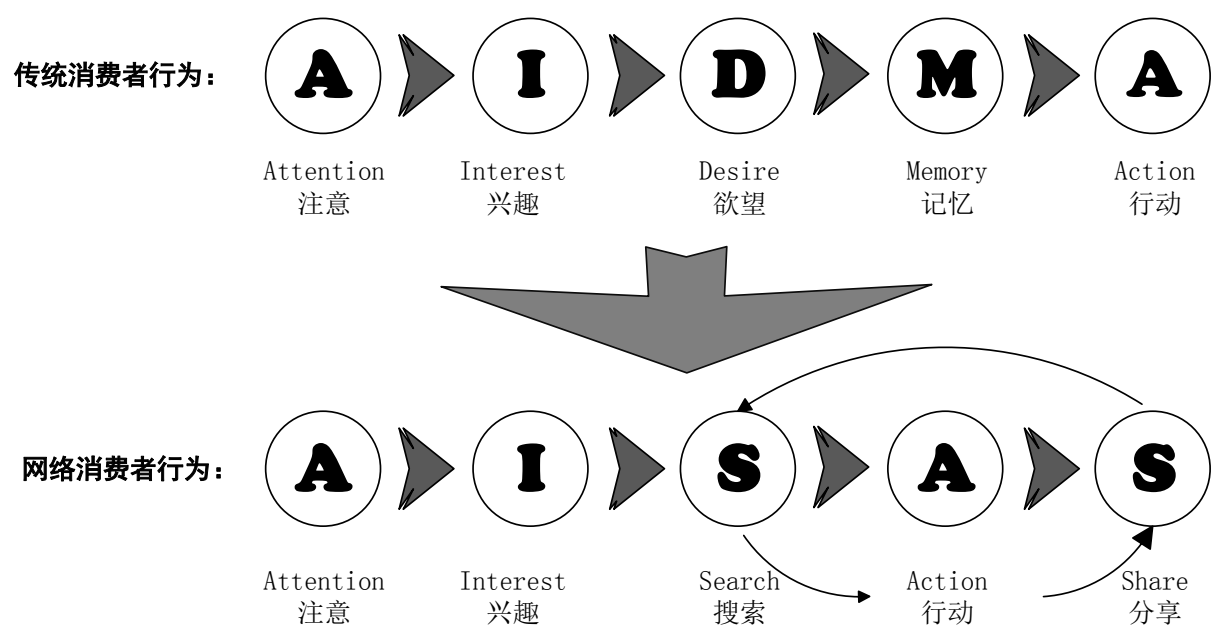

Figure 2. AISAS Model Flow Chart

Base on the network environment of the AISAS model know that consumers in the process of online shopping are active. After they get the information of goods and services on the Internet, they will search the part which they are interested in. Once purchase, they would take the initiative to share. And this share link can influence other consumers in a certain extent, then repeat such a search - action - sharing process cycle again. Thus, the model processes are: attract attention (Attention), stimulate interest (Interest),information search (Search), generate action (Action), information sharing (Share). 


\subsection{Microblogging Marketing Features}

Due to the specific attributes of the micro-blog marketing environment, this paper optimize the TAM model base on the following considerations :

(1)Micro-blog is an open platform, according to the characteristics of online shopping, the process have a certain degree of risk;

(2)Take the initiative to search information and share behavior is very important to the consumption patterns of users under the network environment;

(3)The nature of microblogging marketing activities are active behavior of initiate actors, so the users' individual characteristics and psychological motivation have an important influence;

(4)Brand influence can affect the customers' perception in some extent.

\subsection{Improved TAM Model}

Base on the above three-part study, this study build a model as the main framework, and pay attention to the influence of various variables on the attitude and behavior of users to participate in micro-blog network. First, keep relevant variables of TAM, at the same time introduce micro-blog users' enterprise brand cognition, individual characteristics and psychological motivation as external variables, second increase the perceived risk as supplement endogenous variable, and third base on the AISAS model increase share behavior's influence to external variables, the specific process just as shown in Figure 3:

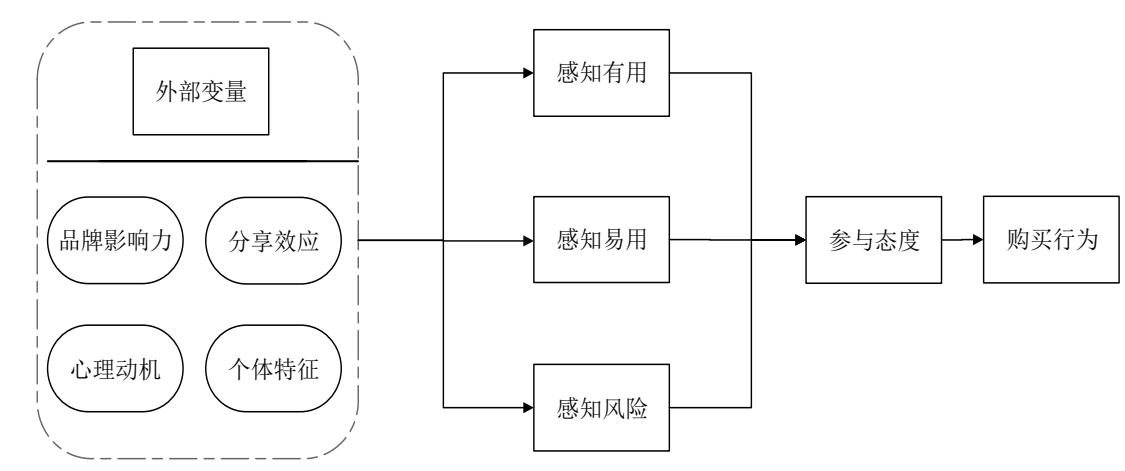

Figure 3. Micro-blog Marketing Impact Factor Research Model

According to the improved TAM model, this essay put forward the following research hypotheses:

$\mathrm{H} 1, \mathrm{H} 2, \mathrm{H} 3$ :brand influence on the enterprise microblogging marketing in the customers' perceived usefulness, perceived ease of use, perceived risk respectively have a significant positive, positive, negative impact;

H4, H5, H6: individual characteristics respectively have a significant positive, positive, negative impact on enterprise microblogging marketing customers' buying behavior perceived usefulness, perceived ease of use, perceived risk;

$\mathrm{H} 7, \mathrm{H} 8, \mathrm{H} 9$ : share effect on enterprise microblogging marketing in customer purchasing behavior perceived usefulness, perceived ease of use, perceived risk have a significant positive, positive and negative effects;

H10, H11 and H12: psychological motivation for enterprise microblogging marketing customer purchasing behavior perceived usefulness, perceived ease of use, perceived risk 
has a significant positive, positive and negative impact;

H13, H14, H15:users' useful perception,ease of use perception, risk perception are respectively have significantly positive, positive, negative impact on the users participation attitude towards enterprise microblogging marketing;

H16: users' participation attitude towards enterprise microblogging marketing can significantly positive influence on the users' purchase behavior.

\section{Empirical-Millet Enterprise Microblogging Marketing Case Analysis}

\subsection{Research Objects}

This paper takes the millet technology enterprise microblogging as an example, studies the influence factors of the customer behavior in the micro-blog marketing activities. Millet technology start with network marketing, have no entity stores. By far March 2016, only millet mobile phone as a single enterprise microblogging has 14.14 million fans, the number of fans ranking first in the enterprise microblogging. Base on this, the questionnaire survey the use of microblogging's millet phone users.

This survey distributes a total number of 826 questionnaires, 633 questionnaires are actual recover, the recovery rate was $76.6 \%$.There have 524 valid questionnaires, the effective rate was $82.8 \%$. The number of valid questionnaires are in accordance with the number of factor analysis required.

\subsection{Questionnaire Reliability and Validity Analysis}

The significance of reliability analysis is to detect the stability of the data in the questionnaire survey, and also detect the consistency and reliability. This paper uses the Cronbach alpha coefficient to measure the results of the data, the higher values represent more reliable items. When $0.6<$ Cronbach $\alpha<0.7$, it means better reliability, greater than 0.8 represents a very good reliability, more than 0.9 on behalf of the reliability of this study is very good. The reliability test results as shown in Table 1.

Table 1. Reliability Test

\begin{tabular}{|c|c|c|}
\hline variables & $\begin{array}{c}\text { Question } \\
\text { number }\end{array}$ & Cronbach's $\alpha$ \\
\hline Brand influence & $1-4$ & 0.901 \\
\hline Individual characteristics & $5-8$ & 0.864 \\
\hline Share Effect & $9-11$ & 0.920 \\
\hline Mental motivation & $12-16$ & 0.951 \\
\hline Perceived usefulness & $17-19$ & 0.841 \\
\hline Perceived ease of use & $20-23$ & 0.828 \\
\hline Perceived risk & $24-26$ & 0.817 \\
\hline Participation attitude & $27-29$ & 0.821 \\
\hline purchase behaviour & $30-31$ & 0.956 \\
\hline total & $1-31$ & 0.757 \\
\hline
\end{tabular}

In this study, in addition to the overall reliability is 0.757 in Cronbach alpha reliability, the rest of the Cronbach alpha coefficient are higher than 0.8.Therefore, the reliability of the data in this study is good, and the reliability is very high.

Validity analysis refers to the validity and accuracy of the questionnaire, and the level of validity represents the accuracy of the measure variables. Validity of this study are analyzed with the methods of KMO test and Bartlett's test of sphericity. KMO can 
measure the partial correlation between variables, the more close to 1, the more common factors between the variables, and it will be more suitable for factor analysis. And if the value is more close to 0 , then it shows that the less common factors between variables. It is generally believed that KMO higher than 0.6 can do factor analysis, the higher the value the more suitable. If the $\mathrm{KMO}$ is less than 0.6 , it is not suitable for factor analysis. If the Bartlett 's spherical test is less than 0.05, it is significant and can reach the significant level, which factor analysis can be done.

This study is carried out KMO and Bartlett's spherical test on 524 data samples, just as shown in Table 2.The KMO value is 0.700 , which is in accordance with the standard of factor analysis. And the spherical test sig. $=0.000$, is less than 0.05 which meets the criteria of significance level. Therefore this questionnaire data is more suitable for factor analysis.

Table 2. KMO Test and Bartlett's Spherical Test

\begin{tabular}{|c|c|r|}
\hline \multicolumn{2}{|c|}{ Kaiser-Meyer-Olkin Sample Measurement } & 0.7 \\
\hline \multirow{4}{*}{ Bartlett's spherical test } & $\begin{array}{c}\text { Approximate chi } \\
\text { square }\end{array}$ & 6427.699 \\
\cline { 2 - 3 } & $\begin{array}{c}\text { Degrees of freedom } \\
\text { (df) }\end{array}$ & 496 \\
\cline { 2 - 3 } & significant(Sig) & 0 \\
\hline
\end{tabular}

\subsection{Structural Equation Model Analysis}

Structural equation model is one of the classical model for data research, mainly through assessment and analysis of the causal relation model, deal with the structural relationship between multiple variables or latent variables. This study will use structural equation model method to analyze the millet microblogging marketing activities and with Amos 22 for fitting assessment and path analysis so that we can get scientific correction model for empirical analysis. Study the model diagram drawn by Amos 22 as shown in Figure 4:

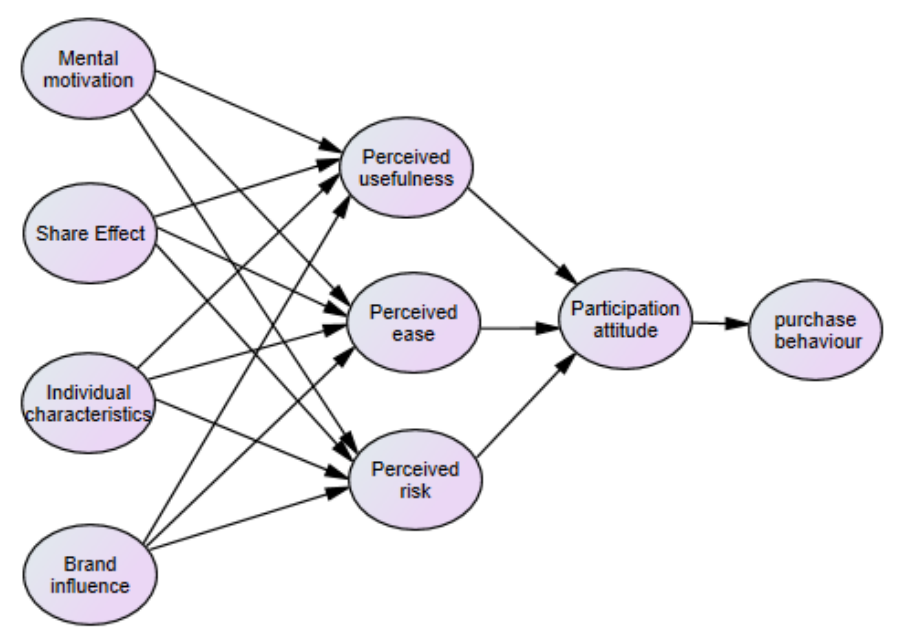

Figure 4. Measure and Path Model 
Table 3. Fitting Effect Analysis

\begin{tabular}{|c|c|c|}
\hline Index & Criteria of effect fitting & $\begin{array}{c}\text { Index value of the } \\
\text { subject }\end{array}$ \\
\hline \multirow{4}{*}{$\chi^{2} / \mathrm{df}$} & $\begin{array}{c}\text { Index value }<3 \\
\text { High degree of model fitting }\end{array}$ & \multirow{4}{*}{$\chi^{2} / \mathrm{df}=1.77$} \\
\hline & $\begin{array}{c}3<\text { Index value }<5 \\
\text { Less high degree of model fitting } \\
\end{array}$ & \\
\hline & $\begin{array}{c}5<\text { Index value }<10 \\
\text { General degree of model fitting }\end{array}$ & \\
\hline & $\begin{array}{c}10 \leq \text { Index value } \\
\text { Model does not fit }\end{array}$ & \\
\hline RMSEA & $\begin{array}{l}\text { Index value is between }(0,1) \text {; The } \\
\text { closer to } 0 \text {, the better the degree } \\
\text { of fitting; RMSEA }<0.1 \text {, model } \\
\text { have a good degree of fitting }\end{array}$ & RMSEA $=0.054$ \\
\hline $\begin{array}{l}\text { Goodness of fit index (GFI)、 } \\
\text { norm of fit index (NFI) 、 } \\
\text { Incremental fit index (IFI) 、 } \\
\text { Comparative fit index (CFI) }\end{array}$ & $\begin{array}{l}\text { All of these Indexes value are } \\
\text { between }(0,1) ; \text { The closer to } 0 \text {, } \\
\text { the better the degree of fitting; }\end{array}$ & $\begin{array}{l}\mathrm{IFI}=0.945 ; \\
\mathrm{CFI}=0.944 ; \\
\mathrm{GFI}=0.891 ; \\
\mathrm{NFI}=0.882\end{array}$ \\
\hline
\end{tabular}

According to the fitting results shown in Table 3, the model hypothesis is basically correct, but there are individual value exceeds the international standard, so the model remains to be continued correction.

Use the model modification indices Amos provided (Modification Index) to extend the model, release some restrictions on path or add some new paths so that the model structure more rationalization. It usually used to improve the model fitting degree. This paper takes a single modification of a path for the principle, when the MI value is greater than 20, the path is modified, the original model of the original output's modified path as shown in the Table 4.

The final structural equation model and the output results are shown in Figure 5, and the path coefficients are normalized.

Table 4. Default Model Path Correction

\begin{tabular}{|c|c|c|}
\hline Modified type & Modified path & Modified Description \\
\hline \multirow{3}{*}{ delete } & e1<-->e 2 & MI=28.46 \\
\cline { 2 - 3 } & e2<-->e 8 & MI=22.19 \\
\cline { 2 - 3 } & e9<-->e10 & MI=30.33 \\
\hline
\end{tabular}




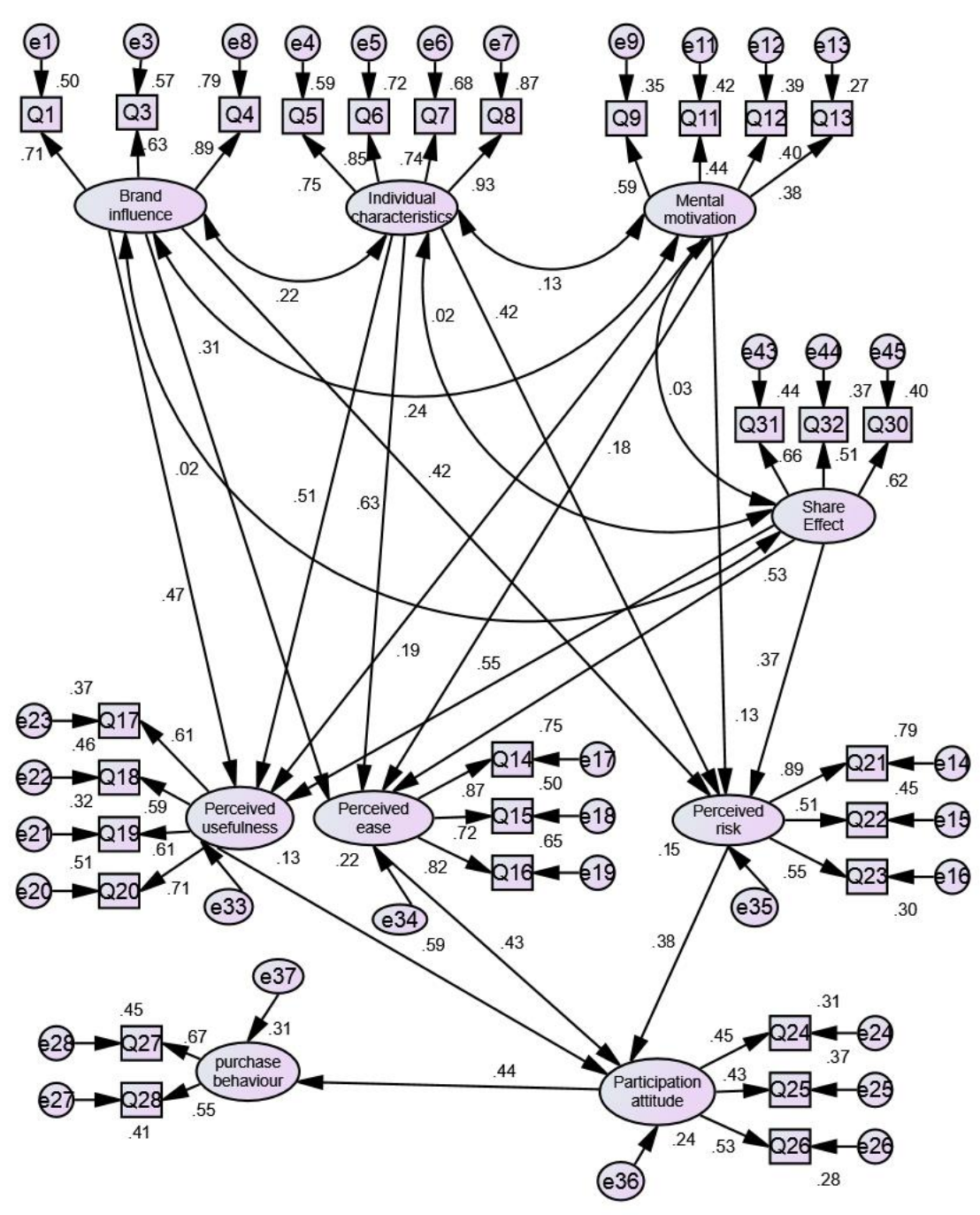

Figure 5. Measure and Path Model

After revise the model, the model fitting of the relate indexes before and after correction are as shown in the Table 5:

Table 5. Correction Model and the Preset Model Fitting Index Contrast

\begin{tabular}{|c|c|c|c|}
\hline Fitting degree index & $\begin{array}{c}\text { Preset model } \\
\text { parameter values }\end{array}$ & $\begin{array}{c}\text { Modified } \\
\text { parameter values }\end{array}$ & $\begin{array}{c}\text { General fitting } \\
\text { standards }\end{array}$ \\
\hline$\square \chi^{2}$ (Chi-square value) & 795.279 & 421.467 & - \\
\hline $\mathrm{df}$ (Degrees of freedom) & 449 & 362 & - \\
\hline $\begin{array}{c}\square \chi^{2} / \mathrm{df} \text { (The ratio of } \\
\text { chi-square and degrees of } \\
\text { freedom) }\end{array}$ & 1.77 & 1.16 & $<3$ \\
\hline $\begin{array}{c}\text { RMSEA (Root mean square } \\
\text { error of approximation) }\end{array}$ & 0.054 & 0.025 & $<0.05$ \\
\hline GFI (Goodness of fit index) & 0.891 & 0.925 & $>0.9$ \\
\hline NFI (norm of fit index ) & 0.882 & 0.916 & $>0.9$ \\
\hline
\end{tabular}




\begin{tabular}{|l|l|l|l|}
\hline IFI (Incremental fit index) & 0.945 & 0.987 & $>0.9$ \\
\hline CFI (Comparative fit index) & 0.944 & 0.987 & $>0.9$ \\
\hline
\end{tabular}

Model after correction, chi-square value decrease from 795 to $421, \chi^{2} / \mathrm{df}$ is optimized from 1.77 to 1.16. At the same time, the value of RMSEA decrease from 0.054 to 0.025 , which has been significantly improved. GFI and NFI are greatly improved, from 0.891 and 0.882 to 0.925 and 0.916 respectively. Therefore, according to the model fitting results come out that the modified model greatly improves its effectiveness, so this study recognize it as the final output model. The path coefficient regression results shown in Table6.

Table 6. Path Coefficient Regression Results

\begin{tabular}{|c|c|c|c|c|}
\hline $\begin{array}{c}\text { Null } \\
\text { hypothesis }\end{array}$ & path & $\begin{array}{l}\text { Standardized } \\
\text { regression } \\
\text { coefficients }\end{array}$ & $\mathrm{P}$ & test result \\
\hline H1 & $\begin{array}{c}\text { Perceived usefulness <---Brand } \\
\text { influence }\end{array}$ & 0.472 & $* * *$ & $\begin{array}{l}\text { Significant } \\
\text { effect }\end{array}$ \\
\hline $\mathrm{H} 2$ & $\begin{array}{c}\text { Perceived ease of use <--- Brand } \\
\text { influence }\end{array}$ & 0.311 & 0.01 & $\begin{array}{l}\text { Significant } \\
\text { effect }\end{array}$ \\
\hline $\mathrm{H} 3$ & $\begin{array}{c}\text { Perceived risk <--- Brand } \\
\text { influence }\end{array}$ & 0.424 & $* * *$ & $\begin{array}{l}\text { Significant } \\
\text { effect }\end{array}$ \\
\hline $\mathrm{H} 4$ & $\begin{array}{l}\text { Perceived usefulness <--- } \\
\text { Individual characteristiccs }\end{array}$ & 0.507 & $* * *$ & $\begin{array}{l}\text { Significant } \\
\text { effect }\end{array}$ \\
\hline H5 & $\begin{array}{l}\text { Perceived ease of use <--- } \\
\text { Individual characteristics }\end{array}$ & 0.631 & $* * *$ & $\begin{array}{l}\text { Significant } \\
\text { effect }\end{array}$ \\
\hline H6 & $\begin{array}{c}\text { Perceived risk <--- Individual } \\
\text { characteristiccs }\end{array}$ & 0.417 & $* * *$ & $\begin{array}{l}\text { Significant } \\
\text { effect }\end{array}$ \\
\hline $\mathrm{H} 7$ & $\begin{array}{c}\text { Perceived usefulness <--- Share } \\
\text { Effect }\end{array}$ & 0.552 & $* * *$ & $\begin{array}{l}\text { Significant } \\
\text { effect }\end{array}$ \\
\hline $\mathrm{H} 8$ & $\begin{array}{c}\text { Perceived ease of use <--- Share } \\
\text { Effect }\end{array}$ & 0.531 & $* * *$ & $\begin{array}{l}\text { Significant } \\
\text { effect }\end{array}$ \\
\hline H9 & Perceived risk <--- Share Effect & 0.369 & $* * *$ & $\begin{array}{l}\text { Significant } \\
\text { effect }\end{array}$ \\
\hline $\mathrm{H} 10$ & $\begin{array}{c}\text { Perceived usefulness <--- Mental } \\
\text { motivation }\end{array}$ & 0.193 & 0.136 & $\begin{array}{c}\text { No significant } \\
\text { effect }\end{array}$ \\
\hline H11 & $\begin{array}{l}\text { Perceived ease of use <--- } \\
\text { Mental motivation }\end{array}$ & 0.181 & 0.154 & $\begin{array}{c}\text { No significant } \\
\text { effect }\end{array}$ \\
\hline H12 & $\begin{array}{c}\text { Perceived risk <--- Mental } \\
\text { motivation }\end{array}$ & 0.134 & 0.094 & $\begin{array}{c}\text { No significant } \\
\text { effect }\end{array}$ \\
\hline $\mathrm{H} 13$ & $\begin{array}{l}\text { Participation attitude <--- } \\
\text { Perceived usefulness }\end{array}$ & 0.588 & $* * *$ & $\begin{array}{c}\text { Significant } \\
\text { effect }\end{array}$ \\
\hline $\mathrm{H} 14$ & $\begin{array}{l}\text { Participation attitude <--- } \\
\text { Perceived ease of use }\end{array}$ & 0.433 & $* * *$ & $\begin{array}{l}\text { Significant } \\
\text { effect }\end{array}$ \\
\hline H15 & $\begin{array}{c}\text { Participation attitude <--- } \\
\text { Perceived risk }\end{array}$ & 0.381 & $* * *$ & $\begin{array}{l}\text { Significant } \\
\text { effect }\end{array}$ \\
\hline H16 & $\begin{array}{l}\text { purchase behaviour <--- } \\
\text { Participation attitude }\end{array}$ & 0.442 & $* * *$ & $\begin{array}{l}\text { Significant } \\
\text { effect }\end{array}$ \\
\hline
\end{tabular}




\section{Conclusions}

\subsection{Model Results}

Comprehensive analysis of the above results, base on the enterprise microblogging marketing activities, get out the verification results of this study in Table7.

Table 7. The Research Hypothesis Testing Results

\begin{tabular}{|c|c|}
\hline Research hypothesis & test result \\
\hline $\begin{array}{l}\text { H1:Brand influence has a significant positive impact on perceived usefulness of } \\
\text { customer purchase behavior; }\end{array}$ & support \\
\hline $\begin{array}{l}\text { H2:Brand influence has a significant positive impact on perceived ease of use } \\
\text { of customer purchase behavior; }\end{array}$ & support \\
\hline $\begin{array}{l}\text { H3:Brand influence has a significant negative impact on perceived risk of } \\
\text { customer purchase behavior; }\end{array}$ & support \\
\hline $\begin{array}{l}\text { H4:Individual characteristics has a significant positive impact on perceived } \\
\text { usefulness of customer purchase behavior; }\end{array}$ & support \\
\hline $\begin{array}{l}\text { H5:Individual characteristics has a significant positive impact on perceived } \\
\text { ease of use of customer purchase behavior; }\end{array}$ & support \\
\hline $\begin{array}{l}\text { H6:Individual characteristics has a significant negative impact on perceived } \\
\text { risk of customer purchase behavior; }\end{array}$ & support \\
\hline $\begin{array}{l}\text { H7:Share Effect has a significant positive impact on perceived usefulness of } \\
\text { customer purchase behavior; }\end{array}$ & support \\
\hline $\begin{array}{l}\text { H8:Share Effect has a significant positive impact on perceived ease of use of } \\
\text { customer purchase behavior; }\end{array}$ & support \\
\hline $\begin{array}{l}\text { H9:Share Effect has a significant negative impact on perceived risk of customer } \\
\text { purchase behavior; }\end{array}$ & support \\
\hline $\begin{array}{l}\text { H10:Mental motivation has a significant positive impact on perceived } \\
\text { usefulness of customer purchase behavior; }\end{array}$ & not support \\
\hline $\begin{array}{l}\text { H11:Mental motivation has a significant positive impact on perceived ease of } \\
\text { use of customer purchase behavior; }\end{array}$ & not support \\
\hline $\begin{array}{l}\text { H12:Mental motivation has a significant negative impact on perceived risk of } \\
\text { customer purchase behavior; }\end{array}$ & not support \\
\hline $\begin{array}{l}\text { H13:Users' useful perceptual has a significant positive impact on their } \\
\text { participation attitude; }\end{array}$ & support \\
\hline $\begin{array}{l}\text { H14:Users' perceived ease of use has a significant positive impact on their } \\
\text { participation attitude; }\end{array}$ & support \\
\hline $\begin{array}{l}\text { H15:Users' risk perception has a significant negative impact on their } \\
\text { participation attitude; }\end{array}$ & support \\
\hline $\begin{array}{l}\text { H16:Users' participation attitude has a significant positive impact on } \\
\text { purchase behavior }\end{array}$ & support \\
\hline
\end{tabular}

This article with TAM and AISAS model as framework mainly analysis enterprise microblogging marketing activities' impact on user behavior, introduce perceived risk, external stimulus, sharing behavior and other variables, design and issue questionnaires, use AMOS 22 for data analysis, the main conclusions are as follows:

(1)In the microblogging marketing activities, the enterprises' brand influence have a relatively strong influence on the users' perception.

(2)Some of the individual users' ability have a strong impact on the users' perception in the microblogging marketing activities.

(3)The sharing behavior of other users in the product have a strong impact on the potential customers' perceived performance. 
(4)The link between users' perception and psychological motivation are weak,from one side illustrate that microblogging marketing activities influence is limited, what microblogging marketing do is to attract the attention of the user.

(5)The degree of users' perceived usefulness will directly strong influence the users' participation attitude of microblogging marketing, and users' participation attitude of microblogging marketing activities in a certain extent strongly influence the customer buying behavior.

\subsection{Recommendations}

In view of the above research results, the following recommendations can be made for the enterprise microblogging marketing to improve enterprise microblogging influence effect:

(1)The enterprise brand influence have a relatively strong impact on the users' perception. Enterprises should expand the visibility, improve the quality or service of the product and strengthen the construction of public relations to enhance the brand influence and value. Increase users' awareness of the brand, search and forward enterprise microblogging actively.

(2)In the enterprises' microblogging marketing activities, accurate position the potential customers is very important. Enterprise should first precise position the upcoming product or activity before locate target customers(like the possible target groups, gender, age, the level of consumption and so on). Only after the first fine position of the product, it is conducive to the next marketing campaign. In the process of users' selection and position the first thing we need to do is that find the target user. Enterprise can through the enterprise microblogging platform push home page to some potential users.

(3)Enterprises should strongly encourage users to share on social media after the purchase of products. Users' sharing action of products are influenced by many factors, including external motivation, personality, product experience, interact with enterprises, etc. Individual users' personality and product experience belong to uncontrollable factors. When enterprises in the best possible to do more excellent products, they can in these two areas enhance the users' desireness to share - the external incentives and user interaction. For the external incentive, on the one hand enterprise can set up some gifts to the outstanding product evaluation, they can also set up series of activities such as sharing bonuses to expand the influence; On the other hand of interaction with the user, enterprises should be as friendly as they can, actively forward users' objective quality evaluation of products, create a harmonious and equitable social media environment.

(4)Enterprise microblogging should make efforts to shape the products' usefulness. Attract users to increase enterprise microblogging attention from the perspective of product usefulness. Enterprise microblogging attract users to quickly become a fan through the usefulness of product(better design, originality packaging),improve users' participation attitude towards enterprise microblogging marketing so that affect purchasing behavior.

\section{Acknowledgments}

Project supported by the National Nature Science Foundation of China (No.71471102); Funded by the Collaborative innovation center of China Three Gorges University for the sustainable development of regional economy and society of the Three Gorges Project(2013YM01). 


\section{References}

[1] D. E. David, S. Mulder and O. J. Vetvik, "The consumer decision journey", Mckinsey Quarterly, no. 3, (2009), pp. 1-11.

[2] B. H. Park, J.-H. Ixe and S.-Y. Park, "Influence SNS users' usage of corporate SNS sites: A study on the factors that focusing on Twitter", The 11th International DSI and the 16th APDSI Joint Conference, (2011); Taipei.

[3] B. J. Jansen, M. Zhang, K. Sobel and A. Chowdury, "Twitter power: Tweets as electronic word of mouth", Journal of the American Society for Information Science \& Technology, vol. 60, no. 11, (2009), pp. 2169-2188.

[4] K. Ehrlich and N. S. Shami, "Microblogging Inside and Outside the Workplace", International Conference on Weblogs and Social Media, (2010); Washington.

[5] E. Diaz-Aviles, P. Siehndel and K. D. Naini, "Exploiting Social \#-Tagging Behavior in Twitter for Information Filtering and Recommendation", Aviles, (2011).

[6] A. E. Kim, T. Hopper, S. Simpson, J. Nonnemaker, A. J. Lieberman, H. Hansen, J. Guillory and L. Porter, "Using Twitter Data to Gain Insights into E-cigarette Marketing and Locations of Use: An Infoveillance Study", Journal of Medical Internet Research, vol. 17,no. 10, (2015), pp. 251-268.

[7] W. Min, "The Research on Media Marketing Based on Mircoblog", Jinan University Dissertation, (2010).

[8] H.-L. Wang, "The Research on the Limitations of Enterprise Microblog Marketing", China university of geoscience(Wuhan)Dissertation, (2011).

[9] Y. Lu, J.-Y. Mao and F.-N. Tu, "Network information aging law studies_— an empirical research of sina news and sina weibo", Journal of Higher Correspondence Education(Philosophy and Social Sciences), vol. 24, no. 12, (2011), pp. 52-55.

[10] Q. Yao and Y.-F. Bu, "Micro-blog's marketing model based on Influence Research", Economic Issues, no. 12, (2011), pp. 117-121.

[11] R. Wang, "Research on Influencing Factors and Short-Term effect measurement of enterprise microblogging Marketing", Beijing University of Posts and Telecommunications Dissertation, (2012).

[12] D. Yu, "Traditional Media Micro-blogging Marketing and its effects to Consumer's Brand Attitude:an Empirical Study", Jinan University Dissertation, (2011).

[13] B.-J. Zhou and L. Hou, "An Analysis of Factors Affecting the Intention of Consumers about Micro-blogging Marketing: Based on TAM and IDT Model", Academic edition of management, no. 12, (2011), pp. 22-40.

[14] J.-P. Ning and X.-Y. Wang, "Design and implementation ofuser analysis function of microblog marketing system", Journal of Computer Applications, vol. 31, no. 2, (2011), pp. 233-236.

[15] F. Ying, "Research on the impact of enterprise micro-blogging marketing on consumer purchasing intention", Zhejiang industry and commerce university Dissertation, (2013).

[16] S.-S. Zhao, "Research on the Influence Assessment and Promotion Strategy of Enterprises' Microblogging", East China Normal University Dissertation, (2014).

[17] H. Mei and H. Yue, "Evaluation of Enterprise Microblogging Event Marketing Effect Based on DEA-Official Microblog of S Enterprise as an Example", Management Review, no. 7, (2015), pp. 137-145.

[18] J.-P. Ge and L.-Q. Shao, "The Marketing and Film Twitter", Contemporary Cinema, no. 2, (2012), pp. $112-115$.

[19] H. Chen, "The model study for sports goods in the micro-blog marketing", Xi'an Physical Culture Institute Dissertation, (2014).

[20] J.-Y. Jiang, "Study on the Strategy of Social Marketing of Audi Brand", Jilin University Dissertation, (2015).

[21] F. D. Davis, "A technology acceptance model for empirically testing new end-user information systems: theory and results", Mit Sloan School of Management, vol. 31, no. 2, (2011), pp. 233-236. 